\title{
How Important Is Green Marketing Mix For Consumer? Lesson From The Body Shop
}

\author{
Siti Sarah Chairunnisa, Idqan Fahmi, and Siti Jahroh \\ Sekolah Bisnis Institut Pertanian Bogor \\ ssaraahc@gmail.com
}

\begin{abstract}
The increasing of consumer needs for cosmetics must be balanced with the care of environmental issues through marketing activities (green marketing). The green marketing concept can be applied in every element of marketing mix comprehensively. The Body Shop is one of the pioneer in cosmetic companies implementing the green marketing mix. The purpose of this study to analyze the effect of green marketing mix towards consumer satisfaction and loyalty. Selected respondents are the consumer who visit the store at least two times within the last six months and above 17 years old. The analysis method used is Structural Equation Modeling (SEM) by SMART PLS software. The result of this study indicate that green marketing mix's effect towards loyalty through consumer satisfaction is higher than green marketing mix's effect towards loyalty directly.
\end{abstract}

Keywords: green cosmetics, green marketing mix, satisfaction, loyalty.

\section{INTRODUCTION}

The cosmetic industry has become one of the main industrial sector in Indonesia, becoming one of the primary needs for both men and women. This phenomenon has also gained the government's intention, represented by the gradually increasing number of the sales rate of cosmetic products in Indonesia for years. The positive trend of the sales rate should be advantageous for cosmetic products in Indonesia. The cosmetic industry in Indonesia has immensely increased, with around 760 companies in 2017, compared to 607 companies in the previous year or 2016 (Ministry of Industry, 2018).

However, fullfilling a consumer's demand on the increasing cosmetic products has to be balanced with the management of the global environment issue. This is an important factor for the companies regarding their sustainability, as the impacts of their business activities towards the natural preservation must be considered. Furthermore, consumers these days are also much smarter in choosing environmeantally friendly products.

There is a marketing concept that concerns with the environmental preservations called the green marketing. The concept, which is promoted by the company and is well-received by consumers (Mathur, 2000), was first introduced as a marketing dimension to solve the limitations of resources in the society (Kumar, 2016). The green marketing can also be defined as a marketing activity that emphasizes the fullfillment of human needs, by paying attention to the possible environmental effects (Polonsky, 2011). In other words, companies that implement the green marketing concept do not only 
respond to consumers' needs for environmentally friendly products, but also maintain the company's long-term sustainability.

The Body Shop Indonesia is one of the cosmetics companies that pioneers the implementation of the green marketing concept. The Body Shop has manufactured body care and beauty products, with various types of products ranging from body care, toiletries, facial care, skin care to hair care. All of its products use natural ingredients, does not use animals as test subjects for the products and campaigns against animal testing. In 2016, The Body Shop globally launched a new commitment, Enrich Not Exploit, It's In Our Hands, affirming The Body Shop's position as a pioneer in the most ethical and sustainable global business in the world.

The Body Shop concerns to the business development in a long term. Company is fulfilling the need of cosmetics with not only considering through good product quality, but also pay attention to every company activities in the surrounding environment. This is because the company has several company values that becomes a commitment which are against animal testing, support community trade, and protect the planet.

The Body Shop Indonesia entered Indonesia in 1992 under PT Monica Hijau Lestari. 95 percent of the products were imported from England, while the skin care products came from Japan, as well as several accessories made by local small businessmen and crafters from Bandung, Salatiga, and Baduy (Angeline, 2015). There are currently more than 120 of The Body Shop counters all around Indonesia, though the actual number remains unclear due to the products' quality or the green marketing concept implemented by the company.

The Body Shop is one of the cosmetic companies that applies the overall green marketing concept through green marketing mix. It can be seen from all outlets spread across Indonesia which able to apply this concept. The Body Shop has a strong commitment to carrying out this concept from its inception until today. Therefore, The Body Shop Indonesia is the most appropriate place to become a place for this research.

This research aims to analyze the effect of implementing the green marketing concept through the green marketing mix approach. The difference between this research and previous researches was the green marketing mix concept would include indicators that addressed environmental and general values to reveal the elements that were considered important by consumers, as well as to increase customer satisfaction and loyalty.

\section{THEORETICAL REVIEW}

Green marketing concept is relatively new to be applied by companies in Indonesia. However, public awareness of environmentally friendly products has begun to increase. So the green marketing concept has begun to accepted by consumer. Before seeing an increase the number of consumers, it is important for companies to know that consumers are satisfied and loyal to the product.

This study looks at the effect of the green marketing implemented by The Body Shop through green marketing mix. The effects of the green marketing mix towards the consumers' loyalty could be seen directly and indirectly (through consumer satisfaction). The marketing strategies through the 4P marketing mix element approach (product, price, 
place, promotion) had a significant impact on various consumer behaviors, such as satisfaction and customer loyalty (Kotler, 2000). Consumer satisfaction was also connected with consumer loyalty, as consumer satisfaction is one of the factors that can directly influence consumer loyalty (Singh, 1991; Chang, 2010). Some of these theories are the basis for structuring relationship between research variables.

Green Marketing Mix. (Kirgiz, 2016) revealed that along with economic growth and profit, companies have begun to consider the benefits for the society in applying the green marketing concept. In this case, the green marketing became the basis of conducting production, marketing and distribution activities in order to influence the demand for its products, by considering the impacts on the environment. The descriptions of each of the green marketing mix elements were as follows.

Green Product. A green product refers to an environmentally friendly product with a recycled process during its production, reducing or eliminating its hazard levels or negative impacts. In addition, the green product indicators can also be seen in environmentally friendly packagings and green labeling systems (Kirgiz, 2016), meaning it does not contain hazardous ingredients for the environment and can be recycled. Green labeling is a green enterprise certification system that is carried out by authorized institutions related to the company's overall system.

Green Price. The establishment of premium prices or regular prices on environmentally friendly products is caused by additional costs to reduce energy use in the production process as well as efficiency of resource usage. In addition, raw materials and environmentally friendly equipment are also obtained at high prices with short-term (Kirgiz, 2016). Therefore, the green price set by the company is usually higher than equivalent products that do not implement the environmentally friendly concept.

Green Place. The green location can be defined as a process that ensures the company's flow of product distribution is executed as plan in all aspects, aiming to fullfill the needs of consumers (Kirgiz, 2016). The indicators include transportations, warehouses, stocks, recipient orders, and logistics activities of the company. However, a green location indicator that is real by consumers is the state of the store where the product is marketed. Outlets with the green place concept will certainly bring consumers in an atmosphere that cares for the environment without forgetting the main purpose of consumers, namely fullfilling their needs.

Green Promotion. The green promotion can be applied to all promotional activities, including advertising; personal selling; sales promotion; point of sale communication; direct marketing; and public relations on the basis of environmental awareness (Kirgiz, 2016). However, companies that implement the green marketing concept do not always carry out all green promotion activities as a whole, due to the different needs and capabilities of the company. 
Satisfaction. Satisfaction is one of the important elements for the company, as a consumer satisfaction determines the success of marketing and sales of the company (Kotler, 2000). The success of the company in providing satisfaction for consumers can also be known as the success in delivering value. Value itself can be a product, service, system or something that is emotional or personal. Satisfaction or dissatisfaction from consumers is a response to the evaluation results between expectations and actual performance. Satisfaction can be said as a reflection of the impact of a product's performance on consumers' feelings. Some indicators to measure customer satisfaction include (Raab et al., 2008):

Cross-Selling. Cross-selling is the purchase of product lines by consumers who are satisfied based on the experience of previous purchases. Satisfied consumers are expected to carry out activities to purchase other products at the same company.

Commitment. A consumer's commitment describes the desire to continue to connect with the company, a bond that is certainly intentional and is based on the consumer satisfaction.

Recommendation. The final expected form of customer satisfaction is the willingness to recommend products voluntarily. Such willingness is conducted by consumers who consciously or unconsciously has gained an experience using related products due to the satisfaction.

Loyalty. Loyalty is when consumers repurchase a product because they are satisfied with the product or brand that has been consumed (Sumarwan, 2017). In other words, repurchase is one form of loyalty that the company is always expecting. Therefore, the approach to consumer loyalty through satisfaction is always important, with several indicators as follows (Tjiptono, 2008):

Repeat. Loyal in purchasing the product is to remain a consumer of the same product in different circumstances, which include the inavailability of the product in the market. Loyal consumers will continue to consume products that have become their choices and is not easily encouraged to try other products. Another form of the consumer loyalty is the existence of the repeat activities. In addition, loyal consumers will also make the product or brand as the first choice in their purchasing decisions.

Retention. Loyalty is also marked by the existence of consumer retention against negative influences on the company. In business development, competitors will continue to carry out activities in order to take over market share.

Referral. Loyal consumers will not be interested in offers that are often given by competing companies, as they will also conduct a referral on the total existence of the company. In addition, a total reference can also be seen in the willingness of consumers to provide advice to companies.

\section{Research Hypothesis}

H1: Green marketing mix has a positive and significant effect on satisfaction.

A marketing mix has a significance towards a consumer's satisfaction in the service industry, in coherence with a research by (Sudarto, 2011). In his research, Sudarto implemented a 7P element as the hospital uses the concept of service marketing strategies, with considerations of process, people, and physical evidence. The research also uses the 
4P elements because it focuses on the concept of marketing the product itself. The research by (Pupuani and Sulistyawati, 2013) with toothpaste products in Denpasar as the object of research revealed that the marketing mix with $4 \mathrm{P}$ elements had a positive and significant effect on consumers' satisfaction. This is in contrast to the research by (Safitri et al., 2017) which showed that only products in the marketing mix element had a positive and significant effect.

H2: Green marketing mix has a positive and significant effect on loyalty.

The implementation of the green marketing mix is also expected to affect consumer loyalty, as seen in the research by (Putra and Suprapti, 2017). The research suggested that the implementation of green marketing through eco-bag shopping bag offers had a significant effect on the loyalty of supermarket consumers. The green marketing concept through the green brand image and green trust approach is also proven to have a direct effect on consumer loyalty (Astini, 2016). Since The Body Shop also implements the green marketing through a marketing mix approach, it is expected to increase the loyalty of the consumers of The Body Shop.

H3: Satisfaction has a positive and significant effect on loyalty.

Consumer satisfaction is also important for the company because it can predict a consumer's behavior that can then form such loyalty (Martin et al., 2007). Researches by (Astini, 2016), (Sidharta and Keni, 2015), and (Wijaya and Istiani, 2015) proved that customer satisfaction had a positive and significant effect on consumer loyalty. In addition, (Dewi and Suprapti, 2018) also revealed the the results were similar to researches on OPPO brand smartphone products. Based on previous studies, the Body Shop's consumer loyalty can be improved through customer satisfaction.

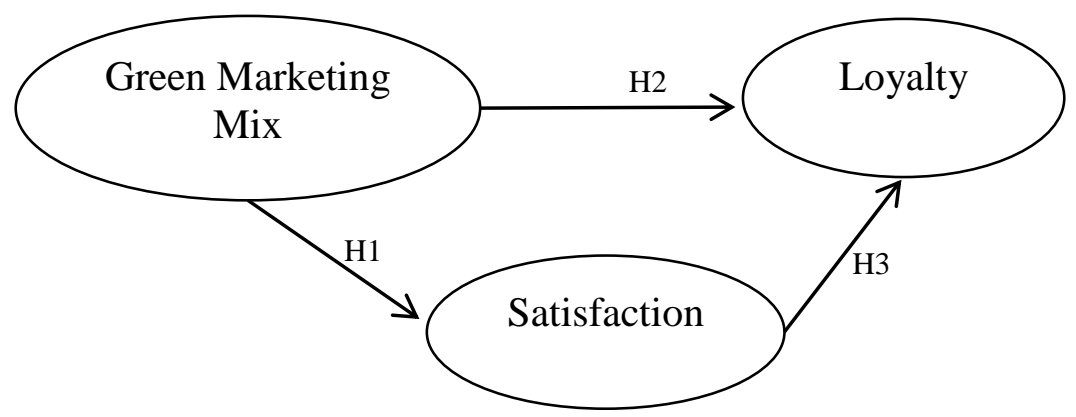

Figure 1. The Conceptual Framework

Furthermore, based on the theory that underlies every research objective and traces of previous researches, the conceptual framework of this research can be shown in Figure 1. The conceptual framework shows the relationship between variables as research hypothesis.

\section{METHODOLOGY}

This research uses a quantitative descriptive approach, by distributing questionnaires to respondents who meet the criteria. Respondents selected as the sample of the research 
were consumers of The Body Shop outlets in Lippo Plaza Ekalokasari, Bogor City, who were over 17 years old and visited outlets at least 2 times during the past 6 months. The research questionnaire is divided into three parts: the screening, the profiling, and the main questions related to research variables.

The number of samples needed for each estimated parameter of exogenous and endogenous variables was five to ten observations (Hair et al., 2006). The number of indicator variables for the SEM model in the study were 22 indicator variables. If for each variable five to ten observations were needed, then the number limit for example was between $22 \times 5=110$ people up to $22 \times 10=220$ people. In addition, this study also included informants who would discuss the research results further. Informants in the study were determined directly from management.

The data collected in the study are primary and secondary. The primary data includes the information about all research variables from questionnaire as the instrument used in the research.. The research questionnaire was divided into three parts, namely screening, profiling, and the main question. The first part of questionnaire starts with screening question to get respondents who are in accordance with the criteria. The second part is profiling to find out the profile of respondents which include name, age, last formal education, occupation, and frequency of visit the outlet. The secondary data is information obtained from various reference sources. The last part is the main question about the research variables which are green marketing mix, satisfaction, and loyalty in the outlet.

The data gathered from questionnaires were later processed using the Structural Equation Modeling (SEM) method, a multivariate statistical analysis technique that could analyze the relationship between complex variables to obtain a comprehensive picture of a model (Ghozali and Latan, 2015). In short, this method could analyze statistical models in the form of causal relationships.

The model evaluation in this research was carried out through analysis of the outer model (measurement model) and inner model (structural model). Outer model analysis was done to measure the validity and reliability of indicator variables in the model, while the inner model analysis determined the causality relationship between latent variables in the research model. The endogenous variables (Y) in this study were customer satisfaction and loyalty, while the exogenous variable $(\mathrm{X})$ in this study was the green marketing measured by the green marketing mix approach. The descriptions of each indicator for the research variable could be seen in Table 1 .

Table 1. The Research Variable

\begin{tabular}{lll}
\hline Variable & Indicator & Symbol \\
\hline Green Marketing Mix & Green Product & \\
(Kirgiz, 2016) & - Made by natural ingredients & GPO1 \\
& - Recyclable packaging & GPO2 \\
& - Durable and long lasting & GPO3 \\
& - Suitable & GPO4 \\
& $\begin{array}{l}\text { Green Price } \\
\text { - Price contains environmental investment cost } \\
\text { - Price according to quality } \\
\text { Green Place }\end{array}$ & GPI1 \\
& GPI2 \\
\hline
\end{tabular}




\begin{tabular}{|c|c|c|}
\hline & $\begin{array}{l}\text { - Distribution channels with environmental values } \\
\text { - Strategic location } \\
\text { Green Promotion } \\
\text { - Promotion with environmental values } \\
\text { - Promotion without environmental values }\end{array}$ & $\begin{array}{l}\text { GPL1 } \\
\text { GPL2 } \\
\text { GPM1 } \\
\text { GPM2 }\end{array}$ \\
\hline $\begin{array}{l}\text { Satisfaction } \\
\text { (Raab, 2008) }\end{array}$ & $\begin{array}{l}\text { Cross-Selling } \\
\text {-Using more than one product } \\
\text {-Willing to try the latest products } \\
\text { Commitment } \\
\text { - Willing to be a member } \\
\text { - Willing to get the latest information } \\
\text { Recommendation } \\
\text { - Willing to inform others } \\
\text { - Always say positive }\end{array}$ & $\begin{array}{l}\text { LIN1 } \\
\text { LIN2 } \\
\text { COM1 } \\
\text { COM2 } \\
\text { REC1 } \\
\text { REC2 }\end{array}$ \\
\hline $\begin{array}{l}\text { Loyaty } \quad \text { (Tjiptono, } \\
2008)\end{array}$ & $\begin{array}{l}\text { Repeat } \\
\text { - Repeat purchase in the future } \\
\text { - The first choice for green cosmetic product } \\
\text { Retention } \\
\text { - Not interested in other green cosmetic product } \\
\text { advertisements } \\
\text { - Not choosing other green cosmetic product } \\
\text { Referral } \\
\text { - Willing to give an advance } \\
\text { - Refer to others }\end{array}$ & $\begin{array}{l}\text { RPT1 } \\
\text { RPT2 } \\
\text { RTN1 } \\
\text { RTN2 }\end{array}$ \\
\hline
\end{tabular}

Source: (Primary Data Processing, 2019)

\section{THE RESULT OF STATISTICAL TEST}

The questionnaire data was gathered in the form of Microsoft Excel and then processed through the Smart PLS 3 application. The evaluation was conducted through the analysis of outer (measurement) and inner (structural) models. The outer model analysis was conducted to measure the validity and the realibility on the indicator variables of the model, while the inner model analysis was intended to find the connection of the causality between laten variables in the research model (Abdillah and Jogiyanto, 2009). 


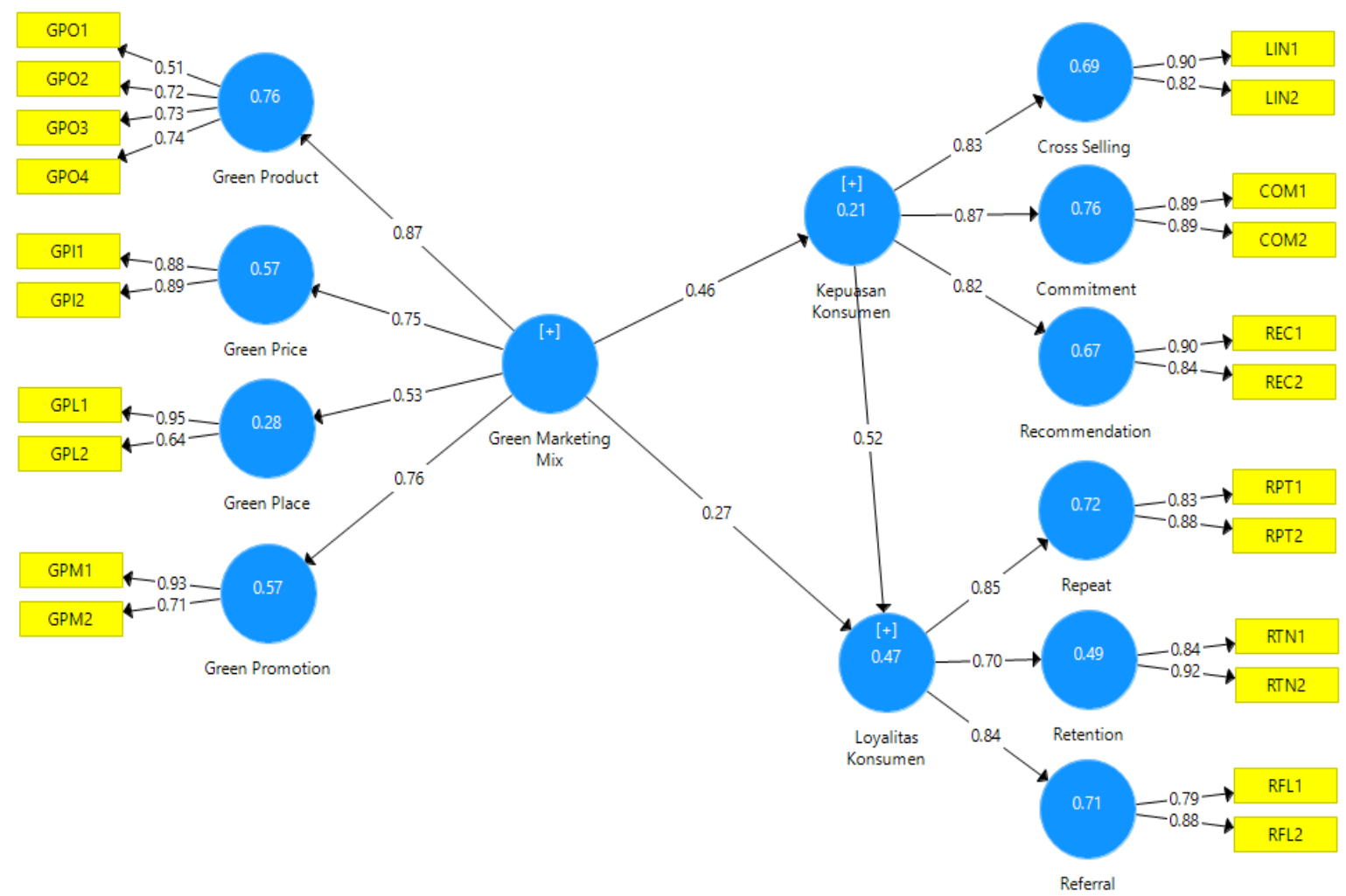

Figure 2. Path Coefficient Value

The measurement model output that showed the path coefficient value was shown in Image 2. In the green marketing mix variable, green product was considered to have the highest path coefficient value, around 0.87 . On green products and green prices, indicators that were considered more important by consumers were indicators of product elements in general compared to indicators that contain elements of the environment. As for green place and green promotion, consumers considered indicators that contained environmental elements to be more important than general marketing mix elements.

In the consumer satisfaction variable, commitment had the highest path coefficient value of 0.87 . This commitment indicator variable had the same path coefficient value of 0.89. Therefore, the willingness to become a member (COM1) and the willingness to receive the latest information about The Body Shop (COM2) had the same level of importance in building customer satisfaction. The indicator variables for product line purchases (cross-selling) and the willingness to provide recommendations (recommendations) had almost the same values, around 0.83 and 0.82 respectively. In cross-selling, the highest level of importance was using more than one of The Body Shop products (LIN1). As for recommendation, the highest indicator is willing to inform The Body Shop to others (REC1).

On the consumer loyalty variable, repeat purchase had the highest path coefficient value of 0.85 , which was the same as the value of the referral indicator variable around 0.84 . In the repeat indicator variable, the willingness of consumers to make The Body Shop as the first choice in choosing environmentally friendly cosmetics (RPT2) was the 
most important to note. The referral indicator variable had a path coefficiency of 0.84 . This indicator variable became the most important indicator to make The Body Shop a reference for environmentally friendly cosmetic products (RFL2). Meanwhile, the retention had the lowest path coefficient value of 0.70 , with the most important indicator was not choosing other environmentally friendly cosmetic products besides The Body Shop (RTN2).

The analysis of the outer or measurement model was conducted through the confirmatory factor analysis, and divided into convergent validity, discriminant validity, and composite reliability tests. The convergent validity test from the results of the outer model could be seen from the loading outer value of each indicator (Ghozali, 2008). The loading outer value that could be received was more than or equal to 0.5. Table 2 also showed that each indicator has met these requirements, which showed that all indicators could reflect variables.

Table 2. Loading Outer Value

\begin{tabular}{|c|c|c|c|c|c|c|c|c|c|c|}
\hline & GPO & GPI & GPL & GPM & LIN & $\mathrm{COM}$ & REC & RPT & RTN & RFL \\
\hline GPO1 & 0.51 & & & & & & & & & \\
\hline GPO2 & 0.72 & & & & & & & & & \\
\hline GPO3 & 0.73 & & & & & & & & & \\
\hline GPO4 & 0.74 & & & & & & & & & \\
\hline GPI1 & & 0.88 & & & & & & & & \\
\hline GPI2 & & 0.89 & & & & & & & & \\
\hline GPL1 & & & 0.95 & & & & & & & \\
\hline GPL2 & & & 0.64 & & & & & & & \\
\hline GPM1 & & & & 0.93 & & & & & & \\
\hline GPM2 & & & & 0.71 & & & & & & \\
\hline LIN1 & & & & & 0.90 & & & & & \\
\hline LIN2 & & & & & 0.82 & & & & & \\
\hline COM1 & & & & & & 0.89 & & & & \\
\hline COM2 & & & & & & 0.89 & & & & \\
\hline REC1 & & & & & & & 0.90 & & & \\
\hline REC2 & & & & & & & 0.84 & & & \\
\hline RPT1 & & & & & & & & 0.83 & & \\
\hline RPT2 & & & & & & & & 0.88 & & \\
\hline RTN1 & & & & & & & & & 0.84 & \\
\hline RTN2 & & & & & & & & & 0.92 & \\
\hline RFL1 & & & & & & & & & & 0.79 \\
\hline RFL2 & & & & & & & & & & 0.88 \\
\hline
\end{tabular}

Source: (Obtain Primary Data Using PLS, 2019)

As the expected AVE value was above 0.5, Table 3 showed that the indicator that had a AVE value below 0.5 was a green product, but the value of 0.46 could still be tolerated. Therefore, each indicator variable was declared valid because the variants of each indicator were well-explained. 
Table 3. AVE Value

\begin{tabular}{lc}
\hline Indicator Variables & $\begin{array}{c}\text { Average Variance Extracted } \\
\text { (AVE) }\end{array}$ \\
\hline Green Marketing Mix & \\
Green Product & 0.46 \\
Green Price & 0.78 \\
Green Place & 0.65 \\
Green Promotion & 0.68 \\
Satisfaction & \\
Cross Selling & 0.74 \\
Commitment & 0.79 \\
Recommendation & 0.76 \\
Loyalty & \\
Repeat & 0.74 \\
Retention & 0.77 \\
Referral & 0.70 \\
\hline
\end{tabular}

Source: (Obtain Primary Data Using PLS, 2019)

The discriminant validity test could be seen from the cross loading value of each indicator in one variable compared to the other latent variables. Table 4 showed that the cross loading value of each indicator in one variable was greater than the correlation with other latent variables. This showed that each indicator variable fullfilled the requirements of the discriminant validity.

Table 4. Cross Loading Value

\begin{tabular}{lccc}
\hline & Green Marketing Mix & Satisfaction & Loyalty \\
\hline GPO & $\mathbf{0 . 8 7 4}$ & 0.434 & 0.420 \\
GPI & $\mathbf{0 . 7 5 2}$ & 0.362 & 0.416 \\
GPL & $\mathbf{0 . 5 2 9}$ & 0.336 & 0.379 \\
GPM & $\mathbf{0 . 7 5 7}$ & 0.186 & 0.289 \\
LIN & 0.352 & $\mathbf{0 . 8 3 2}$ & 0.474 \\
COM & 0.407 & $\mathbf{0 . 8 7 3}$ & 0.550 \\
REC & 0.386 & $\mathbf{0 . 8 1 7}$ & 0.591 \\
RPT & 0.400 & 0.631 & $\mathbf{0 . 8 5 0}$ \\
RTN & 0.358 & 0.271 & $\mathbf{0 . 6 9 8}$ \\
RFL & 0.457 & 0.595 & $\mathbf{0 . 8 4 0}$ \\
\hline
\end{tabular}

Source: (Obtain Primary Data Using PLS, 2019)

The evaluation of the next outer model could be shown from the consistency of measurement (reliability) through the composite reliability test. The expected composite reliability value and cronbach's alpha were greater than 0.5 for each indicator variable. Table 5 showed that each indicator variable had a reliability composite value and 
cronbach's alpha was more than 0.5 , which indicated that each indicator variable had good consistency in measuring latent variables.

Table 5. Composite Reliability and Cronbach's Alpha Value

\begin{tabular}{lcc}
\hline Indicator Variables & Composite Reliability & Cronbach's Alpha \\
\hline Green Marketing Mix & & \\
Green Product & 0.77 & 0.61 \\
Green Price & 0.88 & 0.72 \\
Green Place & 0.79 & 0.53 \\
Green Promotion & 0.81 & 0.57 \\
Satisfaction & & \\
Cross Selling & 0.85 & 0.66 \\
Commitment & 0.88 & 0.73 \\
Recommendation & 0.86 & 0.68 \\
Loyalty & & \\
Repeat & 0.85 & 0.65 \\
Retention & 0.87 & 0.71 \\
Referral & 0.82 & 0.58 \\
\hline Source: (Obtain Primary
\end{tabular}

Source: (Obtain Primary Data Using PLS, 2019)

The evaluation of the inner model could be conducted by looking at the determinant coefficient $\left(\mathrm{R}^{2}\right)$ and the Goodness of Fit Index $(\mathrm{GoF})$. The determinant coefficient $\left(\mathrm{R}^{2}\right)$ measured how much the dependent variable could be influenced by independent variables (Abdillah and Jogiyanto, 2009). The pure independent variable in this study was the green marketing mix (green marketing mix). The pure dependent variable in this study was consumer loyalty. Lastly, consumer satisfaction became both dependent and independent variables.

Table 6 showed the value of $\mathrm{R}^{2}$ from the variables in this study. Consumer satisfaction variables influenced by the green marketing mix variable had an $\mathrm{R}^{2}$ value of 0.21 . This showed that the variable consumer satisfaction could be explained by the green marketing mix variable of 21 percent. Meanwhile, the consumer loyalty variable influenced by the green marketing mix variable and customer satisfaction had an $\mathrm{R}^{2}$ value of 0.47 , meaning that the variable consumer loyalty could be explained by the green marketing mix variable and consumer satisfaction by 0.47 percent. The $\mathrm{R}^{2}$ category was divided into three categories: weak (0.19), moderate (0.33), and substantial (0.67). Therefore, the variable of customer satisfaction was between weak and moderate, while the variable consumer loyalty was between moderate and substantial.

Table 6. $\mathrm{R}^{2}$ Value

\begin{tabular}{cc}
\hline Variable & $\mathbf{R}^{2}$ Value \\
\hline Satisfaction & 0.21 \\
Loyalty & 0.47 \\
\hline
\end{tabular}

Source: (Obtain Primary Data Using PLS, 2019) 
Furthermore, the value of the Goodness of Fit Index (GoF) must be done manually using the following formula:

$$
G o F=\sqrt{\overline{A V E} \times \overline{R^{2}}}
$$

The results of the GoF calculation in this study were 0.58 . GoF values are divided into three categories: small GoF values (0.10), moderate GoF values $(0.25)$, and large GoF values (0.38). Based on these conditions, the GoF value on this model as classified as a large GoF rate.

The value of bootstrapping results could show the influence between latent variables and between latent variables and indicator variables. Table 7 displayed the bootstrapping results which showed that each variable had a significant effect with a calculated $\mathrm{T}$ value greater than 1.96 .

Table 7. The Result of SEM Model Estimated (Direct Effect)

\begin{tabular}{l|c|c}
\hline \multicolumn{1}{c|}{ Variabel } & Path Coefficient & T Value \\
\hline Green Marketing Mix $\rightarrow$ Satisfaction & 0.46 & 6.33 \\
\hline Satisfaction $\rightarrow$ Loyalty & 0.52 & 7.39 \\
\hline Green Marketing Mix $\rightarrow$ Loyalty & 0.27 & 3.71 \\
\hline
\end{tabular}

Source: (Obtain Primary Data Using PLS, 2019)

This study also saw the indirect effect of green marketing mix on consumer loyalty through customer satisfaction. The value of the influence was shown in Table 8 .

Table 8. The Result of SEM Model Estimated (Indirect Effect)

\begin{tabular}{l|c|c}
\hline \multicolumn{1}{c|}{ Variabel } & Specific Indirect Effect & Total Effect \\
\hline $\begin{array}{l}\text { Green Marketing Mix } \rightarrow \\
\text { Satisfaction } \rightarrow \text { Loyalty }\end{array}$ & 0.24 & 0.51 \\
\hline
\end{tabular}

Source: (Obtain Primary Data Using PLS, 2019)

\section{DISCUSSION}

H1: Green marketing mix has a positive and significant effect on satisfaction.

The research results showed that the effect of green marketing mix on consumer satisfaction has been positive on the real level of 0.05 . The highest coefficient of the green marketing mix indicator path was the green product, with a value of 0.87 , showing that green products were the most important elements considered by consumers in the green marketing mix. As for consumer satisfaction, all indicators had almost the same path coefficiencies, therefore each indicator had the same important role in building customer satisfaction. It indicated that the role of green products on each indicator of customer satisfaction must be considered. 
The results are supported by the previous researches which are also carried out on testing the same variable. The results by (Parlan et al, 2016) showed that the green marketing mix had a significant positive effect on customer satisfaction, with the object of research was beauty products with the green marketing concept, but with different other variables. (Parlan et al., 2016) focused on the influence of purchasing decisions that were intermediaries between green marketing mix variables and customer satisfaction. A research by (Devi et al., 2015) showed that the consumer satisfaction was influenced by prices. Another equation was the analysis tool using the SEM PLS, while the difference showed that not all marketing mixes were thoroughly tested as in this study. The research by (Amalia and Novianti, 2016) also supported the statement that the entire marketing mix had a positive effect on customer satisfaction. The difference was that the research implemented the general marketing mix variable and the selection of research objects.

The green marketing mix becomes one of the factors that influences consumer satisfaction. Every green marketing mix element must be considered in order to maintain and improve customer satisfaction. In consumer satisfaction, commitment is an indicator that is considered the most important by the counselor. This commitment could be seen from the willingness to become a member in the future. The Body Shop could improve such relationship between consumers and companies through members. Consumers must get benefits that could increase the customer satisfaction. This member could also encourage consumers in the dissemination of information regarding the latest products and ongoing promotions.

H2: Green marketing mix has a positive and significant effect on loyalty.

Based on the results of the research, the effects of the green marketing mix on consumer loyalty was positive on the real level of 0.05 . On the consumer loyalty, the highest path coefficient was the repeat purchase indicator, with a value of 0.85 . Therefore, the green product as the highest indicator of the green marketing mix variable must be considered by the company, assuring consumers to continue their repeat purchases in order to establish consumer loyalty. Quality green products would become the main reason consumers in faithfully purchasing a beauty product.

Similar results were shown in a research by $(\mathrm{Hu}, 2011)$ which focused on the object of retail research in Taiwan. However, the marketing mix variable in the research did not contain environmental elements. In his research, $(\mathrm{Hu}, 2011)$ also encountered differences regarding other variables of concern, namely brand equity and service quality. However, the findings obtained in this research were the same, the marketing mix must be considered in building consumer loyalty, especially the product element.

Every company expects to gain loyal consumers. This research showed that the most important indicator in building customer loyalty was repurchasing in the future. With a green marketing mix approach that could influence consumer loyalty, every element of the green marketing mix must be able to make consumers continue to buy The Body Shop products in the future. The products included the latest products and products commonly purchased by consumers, as one of the advantages possessed by The Body Shop was an attractive product that came out exclusively. Each product issued in a limited edition needed to be informed to consumers well so that it could increase consumers' desire to try every new product released by The Body Shop.. 
H3: Satisfaction has a positive and significant effect on loyalty.

Based on the results of the research, the effect of consumer satisfaction on consumer loyalty was positive on the real level of 0.05 . The similar results could be found in many previous researches, such as the research by (Widiyanti, 2016) with the object of micro credit debtor research, and (Anggia et al., 2015) with the research object of newspaper consumers. The results of (Amryyanti et al., 2013) also showed the same results with similar research objects, such as consumers of cosmetic products. However, there were other variables besides the marketing mix, namely the quality of services, products, and the fairness of prices.

(Afshar et al., 2011) also revealed that in building a consumer loyalty, consumer satisfaction with products was the most important element to consider. This was in accordance with the results of this research which showed green products as the most important element considered by consumers. The results of the (Asadi et al, 2014) study also indicated a positive and significant influence between satisfaction and consumers by paying attention to product pricing strategies.

This showed that customer satisfaction became important for the company because it would build a consumer loyalty. Consumer satisfaction could be be built by considering each indicator that built the variables of consumer satisfaction itself. Furthermore, companies must also maintain consumer loyalty by paying attention to each indicator variable that built this variable.

In this research, there were indirect influences, namely green marketing mix on consumer loyalty through customer satisfaction. The results of data processing indicated that there was an indirect effect of 0.24 , while the direct effect of green marketing mix on consumer loyalty was 0.27 . The influence of the total green marketing mix on consumer loyalty through customer satisfaction was 0.51 . Therefore, the influence of green marketing mix indirectly or directly through customer satisfaction was greater and should be a concern for the company.

The results were also supported by researches from (Wahab et al., 2016) and (Moraga et al., 2008), showing that the marketing mix had an indirect influence on consumer loyalty through customer satisfaction. (Raksha, 2011) also revealed that the green marketing mix had an indirect influence on consumer loyalty through customer satisfaction, suggesting that every element of the green marketing mix must be structured with the right strategy in order to obtain a good impact on customer satisfaction and loyalty. Therefore, The Body Shop as a company that implements every element of the green marketing mix must be able to increase customer satisfaction and loyalty.

\section{CONCLUSION}

The Body Shop has implemented the green marketing mix element in an overall way. Consumer assessment of the application of products and prices for the marketing mix containing environmental elements was lower than the application of product elements and prices for the marketing mix in general. Meanwhile, place elements and promotions were the opposite. In the green marketing mix variable, the indicator variable considered as the most important by consumers was the green product. 
The analysis results indicated that the green marketing mix had a positive influence on consumer loyalty directly. Green marketing mix also proved to have a positive influence on customer satisfaction, as well as on consumer loyalty. However, the greatest total influence was the green marketing mix on consumer loyalty through customer satisfaction.

Green marketing mix and customer satisfaction become factors that influence loyalty. In maintaining consumer loyalty, companies must pay attention to every element that is considered important by consumers. In green marketing mix, green product was the most important factor. However, product elements with environmental values were still lower than products in general. This showed the need for education related to the environmental value of the company to increase the consumer awareness of environmentally friendly cosmetic products. In consumer satisfaction, commitments which could then be realized in membership (members) became the most important for consumers. While for consumer loyalty, future repurchases became the most important.

A suggestion that can be given based on the results of research to The Body Shop is in a form of several managerial implications that can be done in all outlets of The Body Shop. Some of these managerial implications could be realized through the green marketing mix approach, including providing education to potential potential customers regarding the environmental value of The Body Shop. In addition, The Body Shop could also disseminate good information regarding distribution channels and promotions related to the environment so that consumer awareness of environmentally friendly cosmetic products continues to increase.

Another suggestion is addressed to entrepreneurs in the cosmetics sector in general, who want to carry out the green marketing concept. They need to educate themselves on matters related to environmental values before applying the green product concept. The green promotion element could be applied by companies, followed by further researches on green marketing that consider other 3Ps (people, physical evidence, process). In addition, further researchers are also recommended to implemented more than two variable indicators to avoid any difficulties in conducting the questionnaire test before the study.

\section{REFERENCES}

Abdillah W, and Jogiyanto H.M. (2009). Konsep dan Aplikasi PLS untuk Penelitian Empiris. Yogyakarta: Badan Penerbit Fakultas Ekonomi.

Afshar AJ, Mohammad AHG, Seyed AM, Khaled N, Seyed MSK. (2011). Study the Effects of Customer Service and Product Quality of Customer Satisfaction and Loyalty. Journal of Humanities and Social Science. 1(7): 253-260.

Amilia S, and Novianti A. (2016). Pengaruh Bauran Pemasaran terhadap Kepuasan Konsumen Warung Kansha di Kota Langsa. Jurnal Manajemen dan Keuangan. 5(1): 459-468.

Amryyanti R, Sukaatmadja I.P.G, dan Cahya K.N. (2013). Pengaruh Kualitas Layanan, Produk, dan Kewajaran Harga terhadap Kepuasan dan Loyalitas Pelanggan pada LnC Skin Care Singaraja. Jurnal Ekonomi dan Bisnis Universitas Udayana. 2(1): 22-29. 
Angeline, M.E. (2015). Hubungan Green Marketing terhadap Pilihan Konsumen. Jurnal Universitas Sam Ratulangi.

Anggia T.R, Kawet L, Ogi I. (2015). Analisis Pengaruh Strategi Promosi, Harga, dan Kepuasan terhadap Loyalitas Konsumen Surat Kabar Manado Post. Jurnal EMBA. 3(2): 1041 - 1050.

Asadi A, Pool JK, Jalilvand MR. (2014). The effect of perceived price fairness through satisfaction and loyalty on international tourist' price acceptance of Islamic-Iranian art products. Education, Business and Society: Contemporary Middle Eastern Issues, 7(4): 201-215.

Astini R. (2016). Implikasi Green Brand Image, Green Satisfaction, dan Green Trust terhadap Loyalitas Pelanggan. Jurnal Manajemen. 20(1): 19-34.

Chang CH. (2010). A Study on Brand Loyalty and Customer Lifetime Value. Journal of Information and Optimization Sciences. 31(3):719-728.

Dewi PSA, and Suprapti NWS. (2018). Membangun Loyalitas Pelanggan melalui Kepuasan yang Dipengaruhi oleh Kualitas Produk, Persepsi Harga, dan Citra Merek. Matrik: Jurnal Manajemen, Strategi Bisnis, dan Kewirausahaan. 12(2): 87-98.

Devi BC, Hoyyi A, Mukid MA. (2015). Analisis Faktor - Faktor yang Mempengaruhi Keputusan Pembelian dan Kepuasan Konsumen pada Layanan Internet Speedy di Kota Semarang. Jurnal GAUSSIAN. 4(3): 485-495.

Ghozali, and Latan H. (2015). Partial Least Squares. Yogjakarta: Universitas Dipenogoro. Ghozali I. (2008). Model Persamaan Struktural. Semarang: BP Universitas Diponegoro.

Hair, Black W, Babin B, and Anderson R, Tarham R. (2006). Multivariate Data Analysis. New Jersey: Pearson Education.

Hu YJ. (2011). How Brand Equity, Marketing Mix Strategy, and Service Quality Affect Costumer Loyalty. The International Journal of Organizational Innovation. 4(1): 59 73.

Kirgiz AC. (2016). Green Marketing: A Case Study of the Sub-Industry in Turkey. Basingstoke: Palgrave Macmillan.

Kotler P. (2000). Manajemen pemasaran-analisis, perencanaan, implementasi dan pengendalian. Jakarta: Erlangga.

Kumar P. (2016). State of Green Marketing Research Over 25 Years (1990 - 2014). Marketing Intelligence \& Planning. 34(1): 137 - 158.

Mathur LK. (2000). An Analysis of the Wealth Effects of Green Marketing Strategies. Journal of Business Research. 50 (1): 193-200.

Martin D, Consuegra, Molina A, Esteban A. (2007). An Integrated Model of Price, Satisfaction, and Loyalty: An Empirical Analysis in Service Sector. Journal of Product and Brand Management. 16(7): 459-468.

Moraga TE, Parraga VAZ, and Gonzales ZF. (2008). Costumer Satisfaction and Loyalty. Journal of Consumer Marketing. 25(5): 302-313.

Parlan AV, Kusumawati A, and Mawardi MK. (2016). The Effect of Green Marketing Mix on Purchasing Decision and Costumer Satisfaction. Jurnal Administrasi Bisnis. 39(1): 172 - 178.

Polonsky MJ. (2011). Transformative Green Marketing: Impediments and Opportunities. Journal of Business Research. 64(12): 1311-1319. 
Pupuani NW,and Sulistyawati E. (2013). Pengaruh Bauran Pemasaran terhadap Kepuasan Konsumen dan Perilaku Pembelian Ulang. E-Jurnal Manajemen. 2(6): 683-702.

Putra AD, and Suprapti NWS. (2017). Implementasi Pemasaran Hijau melalui Penawaran Tas Belanja Eco-bag untuk Meningkatkan Loyalitas Pelanggan Pasar Swalayan. Matrik: Jurnal Manajemen, Strategi Bisnis, dan Kewirausahaan. 11(1): 40-51.

Raab G, Ajami RA, Gargeya VB, and Goddard GJ. (2008). Customer Relationship Management: A Global Perspective. England: Gower Publishing Limited.

Raksha R, Majidazar M. (2011). Evaluation of Effectiveness of Green Marketing Mix on Consumer Satisfaction and Loyalty. Middle East Journal of Scientific Research. 10 (6): 755-763.

Safitri SA., Suharno., and Fariyanti A. (2017). Bauran Pemasaran Kepuasan dan Loyalitas Pelanggan Benih Kelapa Sawit PT Socfin Indonesia. Jurnal Manajemen. 21(1): 71-89.

Sidharta EL, and Keni. (2015). Pengaruh Service Fairness, Empathy dan Physical Environment terhadap Customer Satisfaction and Customer Loyalty. Jurnal Manajemen. 19(2): 263-279.

Singh J. (1991). Understanding The Structure of Consumer Satisfaction of Service Delivery. Journal of The Academy of Marketing Science. 19(3): 223-244.

Sudarto T. (2011). Analisis Pengaruh Bauran Pemasaran terhadap Kepuasan Pasien Rawat Inap di Rumah Sakit Kelas VIP. Balance Economics, Business, Management, and Accounting Journal. 8(14): 66-74.

Sumarwan U. (2017). Pemasaran Strategik: Perspektif Perilaku Konsumen dan Marketing Plan. Bogor: IPB Press.

Tjiptono F. (2008). Strategi Pemasaran Edisi Ketiga. Yogyakarta: ANDI.

Wahab NA, Hassan LFA, Shahid SAM, Maon SM. (2016). The Relationship Between Marketing Mix and Costumer Loyalty In Hijab Industry: The Mediating Effect of Customer Satosfaction. Procedia Economics and Finance. 37: 366-371.

Widiyanti S. (2016). Analisis Pengaruh Kepuasan dan Loyalitas Kepercayaan Merek terhadap Loyalitas Debitur Kredit Mikro. [tesis]. Bogor(ID): IPB.

Wijaya PSM, and Istriani E. (2015). Pengaruh Faktor - Faktor Anteseden E-Customer Satisfaction, E-Customer Trust, dan Compulsive Buying pada Pembentukan E-Customer Loyalty. Jurnal Manajemen. 19(1): 1-13. 